2006; 118 (2):488-500.

2. Parisi MA, Ramsdell LA, Burns $M W$, et al. Gender Assessment Team: experience with 250 patients over a period of 25 years. Genet Med. 2007; 9(6):34857.

Дата надходження до редакції 08.10.2018р.
3. Shcherbak $Y$, Globa $Y$, Zelinska $N$, Shevchenko I. [Disorders of testicular development in persons with 46, XY-gonadal dysgenesis]. Clinical Endocrinology and Endocrine Surgery. 2018; (3):15-21. [Ukrainian].

https://doi.org/10.24026/1818-1384.4(64).2018.150171

\title{
РАННЕЕ ВЫЯВЛЕНИЕ СУБКЛИНИЧЕСКОГО АТЕРОСКЛЕРОЗА И ДИАБЕТИЧЕСКОЙ АНГИОПАТИИ У ПАЦИЕНТОВ С САХАРНЫМ ДИАБЕТОМ ПО РЕЗУЛЬТАТАМ ДУПЛЕКСНОГО СКАНИРОВАНИЯ АРТЕРИЙ
}

\author{
О.А. Ковалевская, З.Г. Крушинская, И.О. Чувикина, О.М. Желиба \\ Украинский научно-практический центр эндокринной хирургии, трансплантации \\ эндокринных органов и тканей МЗ Украинь
}

Цель: Изучить возможности и диагностическое значение ультразвукового дуплексного сканирования в оценке субклинических изменений артериальной стенки у больных сахарным диабетом.

Материалы и методы. Нами обследовано 2264 пациента с сахарным диабетом 2 типа (средний возраст 62 года), которые находились на стационарном лечении, и 1972 пациента (средний возраст 54 года), которые проходили обследование и лечение амбулаторно в УНПЦЭХиТЭОиТ (г. Киев).

Пациентам выполнены стандартные клинические, лабораторные и инструментальные исследования, ультразвуковые исследования сердечнососудистой системы (эхокардиография, дуплексное сканирование периферических артерий), все пациенты проконсультированы кардиологом.

При наличии показаний выполнялись КТангиография с контрастированием, рентгенконтрастная ангиография коронарных и периферических артерий.

Результаты и обсуждение. Большинству пациентов (83\%), которые попадают в специализированные лечебные учреждения с поздними сосудистыми осложнениями СД, ультразвуковые исследования сердца и сосудов ранее не назначались и не выполнялись. Эректильная дисфункция - это маркер поражения эндотелия, и может рассматриваться как ранний и значимый независимый фактор риска СД и ССЗ, особенно у мужчин молодого возраста. Коронарная болезнь при сахарном диабете характеризуется бессимптомным, атипичным течением. Диабетическая полинейропатия и малоподвижный образ жизни у пациентов с сахарным диабетом приводят к отсутствию жалоб на I-II стадиях хронической ишемии и обращению за медицинской помощью на III-IV стадиях хронической ишемии нижнихконечностей.Придуплексномсканировании периферических артерий изменения, характерные для диабетической макроангиопатии, выявлены у 97\% пациентов с СД 2 типа. Облитерирующий атеросклероз артерий нижних конечностей выявлен у 26-47\% обследованных пациентов, сосудов головного мозга - у 35-53\%, ИБС - у 55-84\% (в зависимости от анализируемых подгрупп).

\section{Выводы}

1.Ультразвуковаядопплерография (УЗДГ-«слепой допплер») и расчёт лодыжечно-плечевого индекса не позволяют выявить ранние субклинические изменения артериальной стенки.

2. Поскольку 65-70\% пациентов с СД 2 типа имеют поражение берцовых артерий с прогрессирующим развитием кальцифицирующего склероза, измерение АД в берцовых артериях при УзДг может быть некорректным и не отражать истинного состояния кровотока в дистальных сегментах нижних конечностей.

3. Дуплексное сканирование артерий позволяет выявить и оценить степень выраженности как начальных субклинических, так и гемодинамически значимых изменений периферических артерий, и является основным методом диагностики и 
динамического наблюдения у пациентов с СД и атеросклерозом.

4.Пациенты сэректильной дисфункцией, особенно в молодом возрасте, должны проходить тщательное всестороннее обследование эндокринной и сердечно-сосудистой систем, включая дуплексное сканирование сосудов, с целью раннего выявления субклинических форм СД и атеросклеротических изменений периферических артерий.

5. Пациентам с ранними атеросклеротическими изменениями перифери-ческих артерий необходимо обследование и динамическое наблюдение эндокринолога с целью раннего выявления или исключения сахарного диабета.

6. Раннее выявление субклинических изменений сосудистой стенки, модификация образа жизни, адекватное и агрессивное лечение факторов риска сахарного диабета и атеросклероза, грамотное и своевременное назначение фармакотерапии (включая статины и ангиопротекторы) самый действенный способ снизить уровень риска фатальных и нефатальных сердечнососудистых осложнений, достигнуть увеличения продолжительности и улучшения качества жизни у пациентов с сахарным диабетом 2 типа.

\section{ЛИТЕРАТУРА}

1. Куликова А.Н. Облитерирующий атеросклероз артерий нижних конечностей на фоне сахарного диабета II типа (этиопатогенез, клиника, диагностика, хирургическое и медикаментозное лечение, профилактика): автореф. дисс. докт. мед. наук: спец. 14.00.27 «хирургия» / Куликова Алла Николаевна; Саратовский государственный медицинский университет. - Саратов, 2009.

2. Прибила О.В. Облитерирующий атеросклероз артерий нижних конечностей - неоцененная опасность при сахарном диабете / O.В. Прибила, О.В. Зинич, Г.А. Мелуа // Український медичний часопис. - 2018. - Т. 2, №2(124). - С.1-4.

3. Сахарный диабет и атеросклероз: эпигенетические механизмы патогенеза. Обзор литературы / Л.К. Соколова, В.М. Пушкарев, Е.И. Ковзун, В.В. Пушкарев, Н.Д. Тронько // Український кардіологічний журнал. - 2017. №6. - С. 104-117.

Дата надходження до редакції 19.10.2018 p.

https://doi.org/10.24026/1818-1384.4(64).2018.150172

\title{
СТРАТЕГІЇ ЛІКУВАННЯ ПАПІЛЯРНИХ ТИРЕОЇДНИХ КАРЦИНОМ ЧЕРЕЗ 32 РОКИ ПІСЛЯ АВАРІЇ НА ЧОРНОБИЛЬСЬКІЙ АЕС
}

\author{
А.С. Коваленко, Ю.М. Таращенко, Б.Б. Гуда, М.Д. Мельник, \\ М.В. Остафійчук \\ ДУ «Інститут ендокринологї та обміну речовин ім. В.П. Комісаренка НАМН України»
}

Ризик розвитку карцином щитоподібної залози у постраждалих у дитячому віці в результаті аварії на ЧАЕС осіб буде зберігатися ще тривалий час. Проведення постійного тиреоїдного скринінгу цієї групи дозволить виявити захворювання на ранніх стадіях розвитку. Основними ключовими питаннями в лікуванні тиреоїдних карцином залишаються: точність доопераційної цитоморфологічної діагностики, стратифікація ризику та агресивність лікування.

Мета: Оцінити результати лікування й визначити оптимальний протокол діагностики, терапії та моніторингу пацієнтів з папілярними тиреоїдними карциномами.
Матеріал та методи. Проведений аналіз лікування 5830 пацієнтів 3 папілярним раком щитоподібної залози за період з 1990 по 2015 роки. Термін спостереження становив від 1 до 25 років після первинної операції, в середньому 11,8 2,1 року. Вік хворих варіював від 7 до 74 років. Середній вік становив $38,3 \pm 7,4$ року. Пацієнтів жіночої статі було 4706 (80,7\%), чоловічої - 1124 (19,3\%).

Результати та обговорення. Папілярні тиреоїдні карциноми раннього післяаварійного періоду характеризувалися коротким попереднім періодом розвитку, високим біологічним потенціалом злоякісності 3 високим рівнем інвазивності (екстратиреоїдна інвазія - 51,7\%, реґіонарне 